\title{
Assessing Environmental Benefits from Investment in Railway Infrastructure
}

\author{
Jasmina Ćetković1, Slobodan Lakić1, Predrag Bogdanovićé, \\ Radoje Vujadinović ${ }^{3}$, Miloš Žarković ${ }^{1 *}$ \\ ${ }^{1}$ Faculty of Economics, University of Montenegro, Podgorica, Montenegro \\ ${ }^{2}$ Institute of Transportation, Belgrade, Serbia \\ ${ }^{3}$ Faculty of Mechanical Engineering, University of Montenegro, Podgorica, Montenegro
}

Received: 21 March 2019

Accepted: 4 June 2019

\begin{abstract}
The implementation of the general objectives of environmental and climate policy implies significant involvement of low-carbon transport. High-speed rail (HSR) transport is particularly interesting, which is, unfortunately, usually not profitable for the owner of this infrastructure. Redirecting passenger and freight traffic from the road to rail improves the economic performance of the HSR, while improving the performance of the environmental protection system by reducing the amount of fossil fuel used by the transport sector and greenhouse gas emissions. The aforementioned economic and ecological benefits usually precede investments in the modernization of the existing railway infrastructure. The aim of this paper is to evaluate the share of environmental benefits in comparison with other benefits on the example of the project of reconstruction and modernization of the railway in Serbia using cost-benefit analysis. The financial analysis of the reconstruction and modernization project for the Novi Sad - Subotica the border with Hungary railway line has not shown a satisfactory level of financial internal rate of return (FIRR), and the final decision on the implementation of the project can be made after carrying out a socio-economic analysis. The socio-economic analysis of the project pointed to the significant contribution of the project to the overall socio-economic well-being of the country and/or region. In the structure of the overall socio-economic benefits from the realization of the project, the savings due to reduced pollution of the environment is predominant, especially in freight traffic. This indicates a high ecological contribution of this and similar projects to the community.
\end{abstract}

Keywords: sustainable development, low-carbon transport, high-speed rail, ecological benefits, cost-benefit analysis

*e-mail: milos.zarkovic87@gmail.com 


\section{Introduction}

Fossil fuels lead to greenhouse gas emissions [1]. While household and industrial sectors have succeeded in reducing or limiting their negative impact on the environment, the transport sector continues to have a growth trend. Particularly in road transport, technological progress is not able to keep pace with the increase in transport demand, as road transport emissions are increasing despite the environmental improvement of conventional vehicles and the development of alternative fuel vehicles [2]. Reasons for the aforementioned are an increase in the number of inhabitants, motorization and transport needs of the population at the global level [3]. In order to adequately mitigate environmental impacts from transport, decision makers need to carefully consider the use of energy and emissions from the entire life cycle [4].

Low-carbon transport is a priority in addressing the growing global problem of climate change [5-6]. Transport is still almost entirely dependent on fossil fuels $(96 \%)$ and accounts for almost $60 \%$ of global oil consumption [7]. Sustainable transport systems, both passenger and freight, should be economically and technically feasible, but also low-carbon or ecologically acceptable. The calculation of the greenhouse gas emissions in transport projects is becoming the primary goal of transport companies as part of an effort to implement national and global strategies to reduce carbon emissions, reduce energy demand and reduce negative environmental impacts [8-9]. In order to meet these challenges, all modes of transport have to be improved in terms of energy efficiency [10]. One way of achieving this is the redirection of transport from road and air to rail transport, while simultaneously continuously developing and improving all segments of rail transport. Rail is not the best solution for all types of transport, but there are areas where there is potential for providing transport solutions in combination with reduced environmental impact. In order for the railway to be an attractive alternative, it must combine energy efficient and economical solutions with good passenger comfort and low environmental impact over the entire lifetime [11].

Ecological, economic and social impacts, associated with a steady increase in global freight transport, have more than ever led to the need for a more efficient and sustainable freight transport system. HSRs can provide a solution because they have the ability to quickly, safely and economically transport goods, which can sufficiently improve trade links within large regions such as the European Union and expand it to Asian countries. HSRs shall comprise specially built high-speed railways equipped for speeds generally equal to or greater than $250 \mathrm{~km} / \mathrm{h}$ and specially upgraded high-speed railways equipped for speeds of the order of $200 \mathrm{~km} / \mathrm{h}$. Additionally, they comprise specially upgraded highspeed railways which have special features as a result of topographical, relief or town-planning constraints, on which the speed must be adapted to each case. The main issues related to freight transport are greenhouse gas emissions and dependence on fossil fuels, which means that freight transport in rail transport will be particularly competitive. Many countries have invested in the development of HSRs, but at present this type of infrastructure is more commonly used for passenger transport than freight, although there is an increasing number of countries that perform HSR freight services. Some HSR systems are not profitable because they do not have enough interest to use. Therefore, the capacity utilization level of these railways is not at the proper level, which requires additional funding and assistance from governments. Redirecting freight transport from roads to railways will improve the HSR economic performance, reduce the amount of fuel used by the transport sector and reduce overall greenhouse gas emissions [12]. Some of the benefits of driving freight through HSRs are [13]:

- Transport of goods by rail emits less pollution from road, air or sea transport.

- Long distance transport is cheaper by rail than by road, sea or air transport.

- Freight transport by rail does not use fossil fuels.

- Redirection of freight on HSR will reduce the number of traffic accidents and congestion on roads and airports.

- HSR is more reliable, and accuracy compared to the scheduled timetable is in the range of $90 \%$ to $99 \%$.

Several UNECE member countries have the goal of redirecting freight transport from roads to railways and river transport. The focus has been changed from the specific objectives in the transport sector to the modal division as a means of improving the environmental sustainability of transport. Bearing in mind the transition from road to rail transport can be a solution to numerous environmental problems [1].

The European Commission in the 2011 White Paper on Transport, "Roadmap to a single european transport area - towards a competitive and resource efficient transport system" (COM (2011) 0144), set out a goal to ensure that the majority of passenger transport in the medium distance is implemented by railway by 2050. In the medium term (by 2030), the length of the existing HSR network should triple and maintain a dense rail network in all member states. In the long run, the European HSR network should be completed [14]. The European Commission's White Paper on Transport seeks to achieve an effective and sustainable balance between different modes of transport. Impact studies of the intermodal transport on the environment show that rail freight transport has better ecological performance compared to intermodal road-rail and road transport [15] - especially when using an electrified railroad [16-17].

During the last decade, many efforts have been made to examine the impact of transport infrastructure on the environment with a clear focus on new HSR lines. The developed methodologies are applicable and 
comparable, although the boundaries of the system are often different. This is why it is not possible to directly compare the values between individual studies [18]. Important deficiencies of data and uncertainty are also related to the transport system itself. Statistics on road infrastructure damage is missing for most parts of Europe, or at least is not available [19].

Transport is important for social, economic and ecological sustainability. The work on sustainable transport systems requires that all aspects of sustainable development be considered [20]. With policies targeting only one aspect, there is a risk that other dimensions of sustainable development may be neglected or even adversely affected [21]. It is therefore necessary to understand that sustainable transport is important for all dimensions of sustainability. The full contribution of transport to sustainable development should be dealt with systematically and be considered through its links to social, economic and environmental policies [1]. Transport policy is facing, at the beginning of the $21^{\text {st }}$ century, an unresolved dilemma: how to reconcile the seemingly unstoppable growth of passenger and freight transport with unwanted harmful social and ecological effects. The concept of sustainable mobility is proposed as a solution to this dilemma, but is struggling to become an operational concept. Therefore, policymakers are faced with a complex decision because there is an urgent need to harmonize economic development and environmental protection while taking into account different social priorities and the consequences of distribution [22].

Policy makers use feasibility studies as an instrument for assessing project justification. The socio-economic appraisal of a project with an impact assessment on the environment is an indispensable aspect of the assessment [1]. In this regard, cost-benefit analysis is a formal process for evaluating a project that is a product of economic constructions of consumer surpluses and externals. In the meantime, this process becomes a formally regulated process for project approval, with the aim of effectively allocating resources [23-24]. Cost-benefit analysis, which includes a financial and socio-economic appraisal of the project, is accepted as one of the most important tools for resolving problems in policy implementation [25]. It is one of the widely accepted and applied methods for assessing large public sector infrastructure projects [26]. The advantages of this analysis are numerous, such as the rationality, creation, evaluation and comparison of different alternatives, taking into account the time value of money, and it represents an important guide for decision makers [27].

The cost-benefit analysis inherently requires the creation and evaluation of at least two options - "do" or "not to do" with estimates from several different scales (nothing, minimum, and everything according to requirements) [28-29]. The decision-makers should assess the effect of an investment - profit or loss, in space and time. Ultimately, this analysis ensures that the net total benefits for society to exceed the net aggregate costs [26]. In the monetization process, based on a socially accepted valuation system, all input data are converted into monetary value, using a real or shadow price [30] that expresses social welfare, which needs to be maximized [31]. This analysis represents the primary method for integrating the economic and environmental aspects of investments, and "can be applied to other issues requiring decisions, such as the rate of exploitation of scarce natural resources and the management of wilderness areas, and to government policies such as regulation" [32]. Cost-benefit analysis takes the factor of time using a discount rate to reduce the value to the present value [24-25]. In essence, it seeks to cover all the direct costs and benefits of the project for users, assign them monetary values, discount them to the net present value, and in the end to finalize the final evaluation of the project [26-27].

Our work aims to evaluate the importance of environmental benefits in terms of other benefits arising from the railway reconstruction and modernization by expanding the capacity and redirecting transport from road to rail using cost-benefit analysis. The analysis was done on the example of the railway reconstruction and modernization project of the Novi Sad - Subotica - state border with Hungary (Kelebija) section. The project is part of a larger project of Hungarian-Serbian railways, which envisages the reconstruction, modernization and construction of the Belgrade-Budapest (Corridor $\mathrm{Xb}$ ) two-lane railway line for mixed passenger and freight transport, at speeds of up to $200 \mathrm{~km} / \mathrm{h}$, in accordance with European standards and Technical Specifications for Interoperability (TSI) of the Trans-European Transport Network (TNT). In the current state, the railway from Belgrade, via Subotica, to the state border with Hungary (E85) is a double-track railway line 183.2 $\mathrm{km}$ long, which is electrified on its entire length (single phase system $25 \mathrm{kV}, 50 \mathrm{~Hz}$ ).

The objective of the railway modernization project for the Novi Sad - Subotica - state border with Hungary section is to create a modern high-performance twotrack railway for mixed (passenger and freight) transport and a speed of up to $200 \mathrm{~km} / \mathrm{h}$ by reconstructing the existing one-way railway and building a second track. The section length is $108,091 \mathrm{~km}$. The parameters for the design of this two-track railway are defined in accordance with multilateral agreements AGC, AGTC, SEECP, TSI and laws and regulations in the field of railway infrastructure in the Republic of Serbia.

\section{Material and Methods}

In order to respond to the defined goal of work, the following research hypotheses have been identified:

H1: Railway reconstruction and modernization projects often do not confirm the justification of investments from the perspective of the investor - the owner of the infrastructure. 
The primary arguments for this hypothesis are the experiences of the countries of southeastern Europe, which point to the lack of adequate financial effects for investors from projects aimed at raising the quality of railway services.

H2: Railway reconstruction and modernization projects lead to high socio-economic benefits as a result of increased redirection of transport from road to rail.

The effects of railway transport modernization projects in the countries of southeastern Europe point to the dominance of socio-economic effects in relation to financial effects as a result of raising the overall level of railway infrastructure services.

H3: In the structure of the overall socio-economic benefits of reconstruction and modernization projects for railways, the savings due to environment pollution reduction are dominant as a result of redirecting passenger and especially freight transport from road to railway.

The main arguments for the third hypothesis are the underdeveloped legislation in the area of road transport impact on the environment, dominant in the countries of southeastern Europe, together with the lower economic development and lower living standard of these countries (GDP, wages, etc.) in relation to EU countries.

As stated above, the defined hypotheses will be tested by conducting a financial and socio-economic analysis on the example of a reconstruction and modernization project for the railway in Serbia (section Novi Sad - Subotica - border with Hungary). Costbenefit project analysis includes financial and socioeconomic appraisal of the project, which has been done in accordance with the current EU methodology [29], taking into account European regulations in the railway transport sector. The analysis started from the predetermined aims for modernization of the railway and certain key assumptions that made possible the most realistic implementation of this analysis.

The financial analysis objective is to assess whether the cash flow of a future project creates adequate and sustainable returns for the infrastructure owner, especially measured by the FIRR and the corresponding financial net present value (FNPV). The analysis includes an evaluation made using key information about input and output values, their prices, and the total time frame of revenue and costs. It is based on the "incremental method," since it involves performing a comparison between the situation in which the project would be implemented (scenario with the project) and the existing situation (scenario without the project).

Contrary to the financial analysis, which evaluates the project from the perspective of the investor-owner of the infrastructure, the socio-economic analysis assesses the contribution of the project to the overall socio-economic well-being of the region or country. The key objective of the socio-economic appraisal is to prove that the net present value of the socio-economic benefits of the project should outweigh the net present value of the project's socio-economic costs, which means that

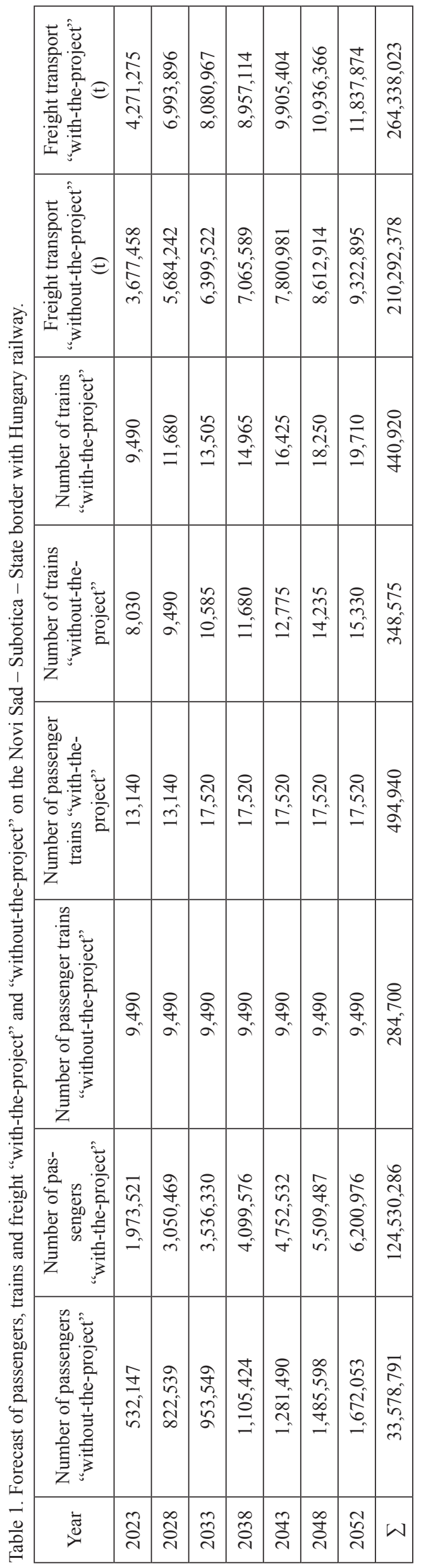


the project has a positive net contribution to society. This is expressed by the positive economic net present value (ENPV), benefit - cost ratio ( $\mathrm{EB} / \mathrm{C}$ ratio) which is greater than 1 , and the economic internal rate of return (EIRR) to be higher than the pre-defined social discount rate.

The implementation of the project financial assessment for the specific case was done with the following basic assumptions:

- The analysis was done in euros.

- The analysis was carried out using fixed prices.

- The initial year of analysis is 2019 .

- The period of investment of funds related to the project is 4.5 years.

- The observed period of project implementation is 2023-2052.

- The final year of the analysis is 2052 .

The financial appraisal of the project is based on transport projections and predicted volume of transport on the railway, both in passenger and freight transport. These projections also served as the basis for the implementation of the socio-economic appraisal of the project. The projections were made on the basis of detailed market analyses and traffic research carried out within the feasibility study [33] for the modernization of the railway shown in Table 1.

Total estimated costs of the project relate to the reconstruction, modernization and construction of the railway Novi Sad-Subotica-Border with Hungary and include the costs of design and construction, expropriation costs and indirect costs, with an estimated total investment of EUR 990,650,000. The dynamic plan of project activity assumes a total project duration of 4.5 years. In addition, for both scenarios - "with-theproject" and "without-the-project," assumed maintenance costs include current and investment maintenance costs. Infrastructure access charges represents almost the only income for the future infrastructure owner. The amount of unit charges is determined subject to the category of the railway line (main, regional, local), train category and type of traction (diesel, electric). Charges for the use of freight and passenger trains are increased by charges for stations and ancillary services use, as shown in Table 2. Data on prices (i.e., fees for access and use of the railway infrastructure) are taken from the statement of the network [34].

In addition to the basic income-infrastructure access charges, direct gains-benefits for owner the infrastructure in the financial analysis are the following:

- Income from additional passenger transport (due to redirection of transport from road to rail).

- Income from freight transport (due to redirection of transport from road to rail).

Projections of the income from transport are calculated on the basis of assumed projections of the transport volume (passenger and freight) and the determined unit price per train/km, both for "withthe-project" and "without-the-project" scenarios. Incremental-additional income for the infrastructure manager is the difference between the incomes under these two scenarios. Incremental-additional income for the infrastructure manager is the difference between the incomes under these two scenarios and range from about EUR 500,000 in the first year of exploitation to about EUR 2,000,000 in the last year of the projection.

In addition to the above, determining the appropriate level of depreciation was necessary for properly defining the lifecycle of certain facilities based on which residual value is determined. Residual value of fixed assets is taken into account in the last year of the evaluation period and it reflects the difference between the real economic operational cycle of the project and the reference period considered within this analysis.

\section{Socio-Economic Appraisal of the Reconstruction and Modernization of the Railway Track}

The socio-economic appraisal of the project has taken into account the same basic assumptions as the project's financial appraisal. The predefined projections of transport forecasts also served as the basis for the implementation of the socio-economic appraisal of the project. The starting point for the calculation of indicators in the socio-economic analysis are the financial flows from the financial appraisal of the project. According to the European Commission's guidelines, the socio-economic benefits of the project are dominantly related to the environment, social aspects and local economic development. Five basic steps for economic evaluation are proposed: conversion of market to shadow prices, monetizing the non-market influence, inclusion of additional indirect impacts, discounting of estimated costs and benefits, and calculating economic performance indicators (ENPV, EIRR and $\mathrm{EB} / \mathrm{C}$ ratio).

Table 2. Charges for the use infrastructure of freight and passenger trains.

\begin{tabular}{|c|c|c|}
\hline Rail category & Charges for freight trains & Charges for passenger trains \\
\hline Main line & 0.7917 EUR/train*km & 0.5278 EUR/train*km \\
\hline Junction & Charges for the use infrastructure of freight trains & Charges for the use of passenger trains \\
\hline Novi Sad & 30.98 EUR/train & 20.65 EUR/train \\
\hline Subotica & $34.69 \mathrm{EUR} /$ train & 23.13 EUR/train \\
\hline
\end{tabular}


Table 4. Average cost relating to air pollution for road and rail transport (EUR/passenger* km).

\begin{tabular}{|c|c|c|}
\hline Tranport modes & $\begin{array}{c}\text { Average cost for } \\
\text { road transport (EUR/ } \\
\text { passenger*km) }\end{array}$ & $\begin{array}{c}\text { Average cost for } \\
\text { freight transport } \\
\text { (EUR/ton*km) }\end{array}$ \\
\hline Road Transport & 0.0270 & 0.3713 \\
\hline Rail Transport & 0.0118 & 0.1239 \\
\hline
\end{tabular}

In the socio-economic analysis, all encompassed prices must be adjusted to "economic values" (without direct and indirect taxes, customs duties, social security costs and any other externalities). We emphasize that in order to calculate the economic value, in accordance with the General Transport Master Plan (GTMP) in Serbia, the conversion factor for construction costs of 0,78 was accepted, and the same factor was applied for maintenance costs. With this economic factor, the economic cost of the investment has been reduced to EUR 972,367,800. At the same time, maintenance costs were reduced by the same conversion factor.

\section{Estimated Economic Savings from the Project}

Within the social-economic analysis of the reconstruction, modernization and construction project of the railway Novi Sad - Subotica - state border with Hungary section, benefits categories are the following:

- Savings due to reduced pollution of the environment.

- Journey time savings.

- Savings in road vehicle operation costs.

- Savings due to reduced number of traffic accidents.

Savings due to reduced pollution of the environment are calculated based on the average cost of air pollution per vehicle* $\mathrm{km}$ calculated on the basis of data collected from several European countries [35]. In order to adjust the proposed values in relation to Serbia, GDP per capita in Serbia and the EU countries was used. According to 2012 prices, the average air pollution costs in Table 4 for passenger and freight traffic are calculated as follows.

Table 5. Projection of savings due to environment pollution reduction caused by shifting freight transport (EUR).

\begin{tabular}{|c|c|c|}
\hline Year & $\begin{array}{c}\text { Savings due to environ- } \\
\text { ment pollution reduction } \\
\text { for road transport }\end{array}$ & $\begin{array}{c}\text { Savings due to environ- } \\
\text { ment pollution reduction } \\
\text { for freight transport }\end{array}$ \\
\hline 2023 & $2,453,795$ & $22,960,853$ \\
\hline 2028 & $3,792,828$ & $38,340,741$ \\
\hline 2033 & $4,396,927$ & $46,190,299$ \\
\hline 2038 & $5,097,244$ & $53,547,216$ \\
\hline 2043 & $5,909,102$ & $61,176,262$ \\
\hline 2048 & $6,850,269$ & $69,215,325$ \\
\hline 2052 & $7,710,038$ & $76,400,768$ \\
\hline Total & $154,835,827$ & $1,581,015,381$ \\
\hline
\end{tabular}

Table 6. Current and forecast journey times in passenger traffic (min).

\begin{tabular}{|c|c|}
\hline Condition & $\begin{array}{c}\text { Novi Sad - } \\
\text { Hungarian border }\end{array}$ \\
\hline Current condition - Passenger cars & 66 \\
\hline Current condition - Buses & 86 \\
\hline Current condition - Railways & 150 \\
\hline Projected condition - Railways & 50 \\
\hline
\end{tabular}

Unit data are based on the handbook on estimation of external cost in the transport sector [36].

Projected savings due to reduced pollution of the environment caused by shifting transport for road and freight transport (from road to rail) are shown in Table 5.

Table 5 represents a calculation of the savings due to environment pollution based on previously presented data in Table 4 and traffic research carried out within the feasibility study [33]. In the final projection of these savings, savings of the same category were added. Those savings are due to reaching the permeability of the existing railway limit in 2047.

Journey time savings are quantified based on traffic volume forecast, projected journey times under "withthe-project" and "without-the-project" scenarios, determined value of time (VOT) and determined unit time value of the train operating cost (TOC).

Forecast traffic volume, number of passengers and number of trains are presented in the previous sections of analysis, while the forecast journey times for "withthe-project" scenario and current journey times, both in rail and in road traffic, are presented in Table 6.

VOT is determined based on the data for business and private travels of passengers, taking into account the appropriate values from the GTMP in Serbia in the amount of $5.32 \mathrm{EUR} / \mathrm{h}$ for business travels and 1.26 EUR/h for private travels [37]. Taking into account the structure as per nature of travel, the average VOT is set at $2.72 \mathrm{EUR} / \mathrm{h}$.

Projections of journey time savings were made both for existing rail passengers and for those shifted from the road to rail. They range from EUR 4.2 million in the first to EUR 13.3 million in the last year of the projection.

Savings in train operating costs are calculated based on data on unit TOCs, which were determined as

Table 7. Train operating costs per hour for passenger train (EUR/h).

\begin{tabular}{|c|c|}
\hline Traction hour unit costs & 255.5 \\
\hline Driver's costs & 8.7 \\
\hline Costs of other passenger train staff & 18.9 \\
\hline Total: & 283.1 \\
\hline
\end{tabular}


Table 8. Existing and projected journey times in freight transport (min).

\begin{tabular}{|c|c|}
\hline Time in freight transport & $\begin{array}{c}\text { Novi Sad }- \\
\text { Hungarian border }\end{array}$ \\
\hline Existing condition - goods vehicles & 86 \\
\hline Existing condition - railways & 144 \\
\hline Projected condition - railways & 74 \\
\hline
\end{tabular}

Table 9. Train operating costs per hour for freight train (EUR/h).

\begin{tabular}{|c|c|}
\hline Traction hour unit costs & $255.5 \mathrm{EUR} / \mathrm{h}$ \\
\hline Driver's costs & $8.7 \mathrm{EUR} / \mathrm{h}$ \\
\hline Total: & $264.2 \mathrm{EUR} / \mathrm{h}$ \\
\hline
\end{tabular}

a result of previous research and analysis [38]. Calculation of train operating costs per hour for passenger train is presented in Table 7.

Projection of passenger train cost savings is calculated based on the unit operating costs of the train and traffic projections and ranges in the amount of EUR 3.6 million in the first to EUR 6.3 million in the last year of the projection.

Forecast traffic volume, freight and number of trains, both for "with-the-project" scenario and "without-theproject" scenario, are presented in the previous sections. Forecast train journey times for "with-the-project" scenario and present journey times are presented in Table 8 .

The data relating to the unit TOC for freight trains were determined as a result of previous research and analyses [38]. Calculation of costs per hour for freight train is given in Table 9.

Projection of savings in freight train operation costs are calculated based on unit TOC and projected volume of freight transport ranging from EUR 2.3 million in the first to EUR 6.4 million in the last year of projection.

Savings in road vehicle operation costs in passenger traffic occur as a result of redirection of transport from road to rail and are quantified for passenger cars and buses based on forecasted traffic volume, determined length of existing and new relations and vehicle operating cost (VOC) of time. The unit VOC in passenger traffic was based on data obtained from previous surveys [39] and amounted to $0.15 \mathrm{EUR} / \mathrm{km}$ for passenger cars and $0.59 \mathrm{EUR} / \mathrm{km}$ for buses. As stated in the study [33], VOC includes the average cost of road vehicles (fuel costs, tire costs, regular and periodic repairs costs, maintenance costs, spare parts costs, etc.) occurring during its exploitation, per one kilometer of road. The projected savings range in the amount of around EUR 9.7 million in the first to EUR 30.5 million in the last year of the projection.

In order to determine savings in road vehicle operation costs in freight transport, based on the shifted freight transport from road to rail, a projection of shifted freight transport to traffic directions was carried out - the regions in Serbia (from and towards which the transport will take place), which is shown in Table 10 that follows.

The unit VOC in freight transport is set at a rate of $0.66 \mathrm{EUR} / \mathrm{km}$ for heavy goods vehicles [39]. The projection of saving the cost of exploitation of road vehicles in freight traffic is done individually for each region and the total savings range from EUR 2.5 million in the first, to EUR 8.1 million in the last year of the projection.

In the socio-economic appraisal of the project, savings in reducing the number of traffic accidents are also calculated. Since statistics show that the number of accidents is lower on a double-track railway than on single-track, in "with-the-project" scenario is expected to reduce the number of traffic accidents due to the shift from road to rail. In the GTMP in Serbia, based on statistical data, the traffic accident rate per passenger * $\mathrm{km}$ travelled has been calculated [37]. Estimates of the numbers of traffic accidents on highways and railways are presented in Table 11.

The calculation of costs arising from traffic accidents has been made on the basis of appropriate data resulting from previous research and analysis [35]. Accordingly,

Table 10. Shifted freight from road to rail $(\mathrm{t})$ - regions.

\begin{tabular}{|c|c|c|c|c|c|c|c|}
\hline Year & Belgrade region & Western region & $\begin{array}{c}\text { Southwestern } \\
\text { region }\end{array}$ & Central region & $\begin{array}{c}\text { Southeastern } \\
\text { region }\end{array}$ & Vojvodina region & Total \\
\hline 2023 & 140,353 & 21,239 & 6,087 & 133,873 & 137,862 & 216,651 & 656,065 \\
\hline 2028 & 249,223 & 37,714 & 10,808 & 237,716 & 244,800 & 384,704 & $1,164,965$ \\
\hline 2033 & 300,247 & 45,435 & 13,021 & 286,385 & 294,918 & 463,465 & $1,403,469$ \\
\hline 2038 & 348,068 & 52,671 & 15,094 & 331,998 & 341,891 & 537,283 & $1,627,006$ \\
\hline 2043 & 397,659 & 60,176 & 17,245 & 379,299 & 390,601 & 613,831 & $1,858,811$ \\
\hline 2048 & 449,914 & 68,083 & 19,511 & 429,142 & 441,929 & 694,494 & $2,103,074$ \\
\hline 2052 & 496,621 & 75,151 & 21,537 & 473,693 & 487,807 & 766,591 & $2,321,400$ \\
\hline Total & $10,266,977$ & $1,553,652$ & 445,242 & $9,792,960$ & $10,084,760$ & $15,848,248$ & $47,991,840$ \\
\hline
\end{tabular}


Table 11. Estimate of number of traffic accidents on highways and railways.

\begin{tabular}{|c|c|}
\hline Highway & $\begin{array}{c}\text { Number of traffic } \\
\text { accidents }\end{array}$ \\
\hline Fatality/billion of passengers*km & 1.6 \\
\hline Serious injuries/billion of passengers*km & 13.497 \\
\hline Minor injuries/ billion of passengers*km & 27.403 \\
\hline \multicolumn{2}{|c|}{ Double track railway } \\
\hline Fatality/billion of passengers*km & 0.1492 \\
\hline Serious injuries/billion of passengers*km & 0.759 \\
\hline Minor injuries/billion of passengers*km & 1.541 \\
\hline \multicolumn{2}{|c|}{ Single track railway } \\
\hline Fatality/billion of passengers*km & 0.2238 \\
\hline Serious injuries/billion of passengers*km & 1.1418 \\
\hline Minor injuries/billion of passengers*km & 2.3182 \\
\hline
\end{tabular}

Source: GTMP in Serbia

Table 12. Unit values of costs of traffic accidents (EUR).

\begin{tabular}{|c|c|}
\hline Unit values of costs of traffic accidents & Amount \\
\hline Cost of fatality & 323,978 \\
\hline Cost of serious injury & 43,254 \\
\hline Cost of minor injury & 3,276 \\
\hline
\end{tabular}

the cost of death is $63.0431 *$ GDP per capita, the cost of serious injuries is $8.41697 *$ GDP per capita, and the cost of minor injuries is $0.63753 *$ GDP per capita. Given that the estimated GDP per capita in Serbia in 2018 was 5,139 EUR, unit values of the costs of traffic accidents were obtained, as shown in Table 12.

Estimating traffic accident cost is based on the estimated number of accidents for rail and road transport for existing and shifted passengers, for the "with-the-project" and "without-the-project" scenarios. In this regard, the estimated total savings in costs of traffic accidents range from about EUR 180 thousand in the first, to around EUR 570 thousand in the last year of the projection.

\section{Estimated Economic Cost of the Project}

In the socio-economic analysis, the basic price of the investment is the same as the financial analysis of the project. The corrective factor $(\mathrm{CF})$ is 0.78 for the part of the investment to which the correction is applied. In order to calculate the economic value using the $\mathrm{CF}$, the following assumptions have been accepted in accordance with the GTMP: CF for domestic materials 0.982 , CF for imported materials 0.884 , CF for domestic equipment $0.871, \mathrm{CF}$ for imported equipment $0.855, \mathrm{CF}$ for power consumption 0.950 .
Table 13. Additional train operational costs category for shifting transport from road to rail (EUR).

\begin{tabular}{|c|c|c|}
\hline Additional cost category & Unit & Amount \\
\hline Energy consumption costs & gross tkm & 0.003174 \\
\hline Freight train crew costs & train $\mathrm{km}$ & 0.31 \\
\hline Passenger train crew costs & train $\mathrm{km}$ & 0.52 \\
\hline Locomotive operation costs & train $\mathrm{km}$ & 1.095 \\
\hline $\begin{array}{c}\text { Freight wagon operation } \\
\text { costs (for the entire train) }\end{array}$ & train $\mathrm{km}$ & 2.385 \\
\hline $\begin{array}{c}\text { Passenger coaches operation } \\
\text { costs (for the entire train) }\end{array}$ & train $\mathrm{km}$ & 1.835 \\
\hline
\end{tabular}

Bearing in mind that taxes and social security account for about $52 \%$ of the labor costs and that unemployment in Serbia reaches up to $19 \%$, the CF for labor costs is 0.389 . The total construction costs consist of $35 \%$ of the labor costs, $58 \%$ of the material costs and $7 \%$ of the equipment costs. Assuming that $30 \%$ of material costs and $70 \%$ of equipment costs are for imported goods, the total CF for construction costs is 0.78. The same CF is applied to maintenance costs.

Additional costs of railway transport arise as a result of road to rail shift, and thereby of the operation of more trains. Data on average train operation costs for Serbian railways provided by PE Serbian Railways for both passenger and freight trains is presented in Table 13.

Therefore, the marginal costs of train operation are for a passenger train $4.7196 \mathrm{EUR} /$ train* $^{\mathrm{km}}$ and for a freight train (electric) 7.5988 EUR/train*km. On the basis of the established marginal costs of train and transport projections, the projection of additional costs for passenger and freight trains range in the amount of around EUR 2.5 million in the first, to around EUR 7.5 million in the last year of the projection.

\section{Results and Discussion}

In the following part results of performed feasibility analysis regarding the reconstruction and modernization railway project are presented. Based on financial and socio-economic balances on net effect of the project, indicators of financial and socio-economic feasibility of the project are established.

\section{Results of Financial Appraisal of the Project}

After determining necessary inputs, financial appraisal of the project was performed, calculating standard dynamic indicators of the investment justification. A prerequisite for dynamic evaluation of project feasibility is establishment of adequate discount rate. In accordance with European Commission recommendations, financial discount 
Table 14. Projection of balance of net effects - financial appraisal (in EUR).

\begin{tabular}{|c|c|c|c|c|c|c|c|}
\hline Year & Investment & $\begin{array}{c}\text { Investment } \\
\text { maintenance }\end{array}$ & $\begin{array}{c}\text { Current } \\
\text { maintenance }\end{array}$ & $\begin{array}{c}\text { Income from } \\
\text { freight transport }\end{array}$ & $\begin{array}{c}\text { Income from } \\
\text { passenger transport }\end{array}$ & $\begin{array}{c}\text { Residual } \\
\text { value }\end{array}$ & Net effects \\
\hline 2019 & $49,532,500$ & & & & & & $-49,532,500$ \\
\hline 2020 & $247,662,500$ & & & & & & $-247,662,500$ \\
\hline 2021 & $297,195,000$ & & & & & & $-297,195,000$ \\
\hline 2022 & $297,195,000$ & & & & & & $-297,195,000$ \\
\hline 2023 & $99,065,000$ & $-29,400,000$ & $-955,500$ & 207,637 & 274,875 & & $-75,576,988$ \\
\hline 2028 & & & $-1,079,636$ & 391,394 & 460,887 & & $1,931,917$ \\
\hline 2033 & & & $-875,388$ & 508,298 & $1,062,652$ & & $2,446,338$ \\
\hline 2038 & & & $-660,753$ & 578,977 & $1,116,421$ & & $2,356,152$ \\
\hline 2043 & & & $-435,203$ & 647,360 & $1,175,787$ & & $2,258,351$ \\
\hline 2048 & & & $-198,183$ & 714,738 & $1,241,332$ & & $2,154,253$ \\
\hline 2052 & & & 0 & 773,655 & $1,298,646$ & $168,678,243$ & $170,750,545$ \\
\hline Total & $990,650,000$ & $-58,800,000$ & $-19,673,909$ & $16,512,904$ & $29,643,906$ & $168,678,243$ & $-697,341,038$ \\
\hline
\end{tabular}

rate has been determined at the level of 4\% [29]. Effects of construction - costs and benefits perceived in the economic lifetime of project, discounted using the above-mentioned established financial discount rate, have been expressed in present values of monetary units.

Projection of the financial balance of net effects of this project is presented in Table 14.

Based on performed calculation of total net effects (Table 14), the following indicators of financial project feasibility have been established:

- FIRR is negative, less than the established discount rate and amounts to $-4.78 \%$.

- FNPV is negative and amounts to -752.42 mil EUR.

- Financial benefit-cost (FB/C) ratio amounts to 0,082, which is less than 1.

Based on results achieved within the financial analysis of justification of the railway reconstruction, modernization and construction project of the Novi Sad - Subotica - State border with Hungary (Kelebija) railway section, it can be concluded that subject investment is not justified for owner of the infrastructure from's exclusively financial point of view. The mentioned project has not been achieving agreeable return of invested funds and has been financially unprofitable. It is important to note that future income of railway use is completely covering operational costs of railway maintenance, which is a prerequisite for its unobstructed operational functioning. However, negative financial indicators of the project cannot serve as an exclusive base for making the decision whether to implement it or not. Final conclusions on investment feasibility should come out based on perceived contribution of the project to the total country's economic welfare and more beyond the region.

\section{Results of Socio-Economic Appraisal of the Project}

A socio-economic appraisal of project feasibility has been performed by implementing standard dynamic indicators of investment justification. According to the European Commission recommendations, the economic discount rate of 5\% has been determined [29]. Projection of economic balance of net effects of this project is presented in Table 15.

Based on performed calculation of total net effects (Table 15), the following indicators of socio-economic feasibility of the project have been determined:

- EIRR is positive, higher than determined discount rate and amounts to $8.15 \%$.

- ENPV is positive, and amounts to EUR 472.93 million.

- $\mathrm{EB} / \mathrm{C}$ ratio amounts to 1.70 .

According to the determined indicators of socioeconomic evaluation of the project, it can be concluded that a project has satisfactory economic justification since EIRR is positive and higher than the discount rate, ENPV is positive, and economic benefit-cost ratio is on a satisfactory level.

\section{Calculation of Environment Benefits}

Table 15 shows that in the structure of socioeconomic benefits from the realization of the project, savings due to reduced pollution of the environment are dominant, especially in freight traffic. Thus, in 2052 these savings were forecasted at the level of EUR 207,540,369 for freight traffic and EUR 7,710,038 for passenger traffic (Fig. 1), i.e., total $73.1 \%$ of the total socio-economic benefits, while the dominant saving of 


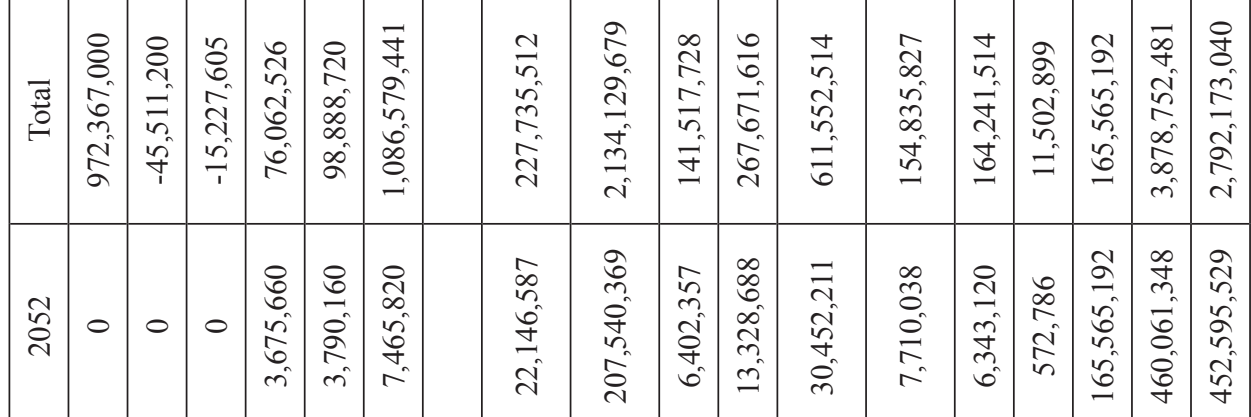



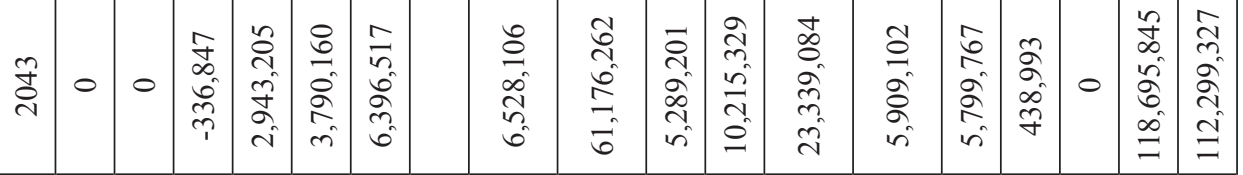

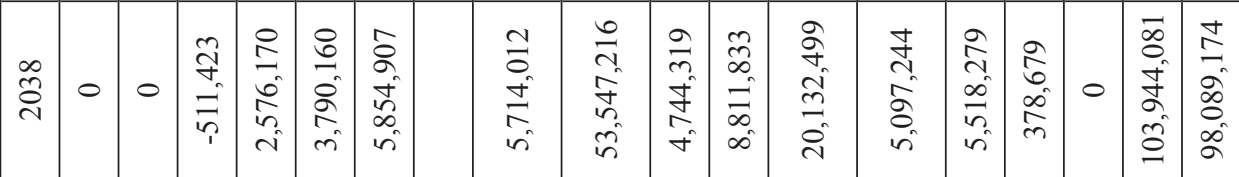

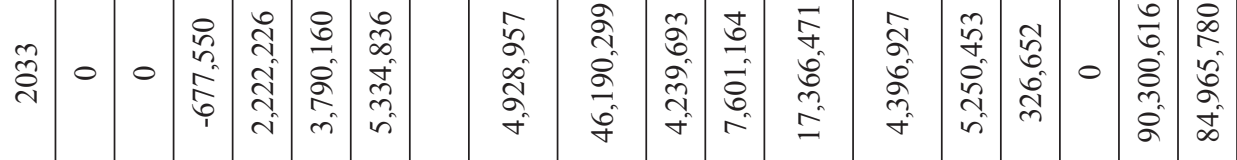

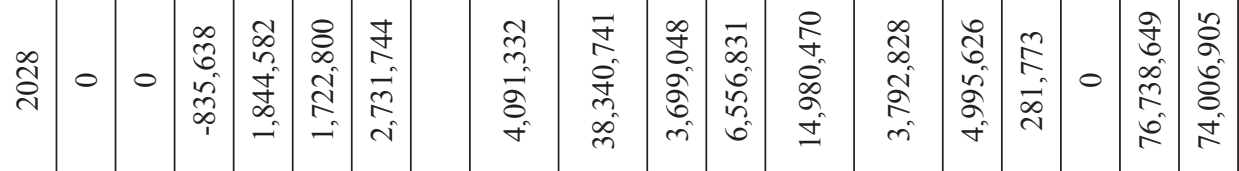

\begin{tabular}{|c|c|c|c|c|c|c|c|c|c|c|c|c|c|c|c|c|c|c|c|}
\hline ๙ิ & 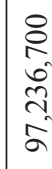 & 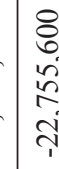 & $\left\{\begin{array}{l}n \\
\hat{n} \\
\hat{n}\end{array}\right.$ & $\begin{array}{l}\infty \\
\stackrel{0}{+} \\
\stackrel{+}{0}\end{array}$ & 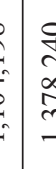 & 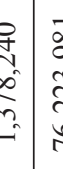 & 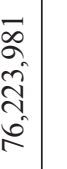 & & 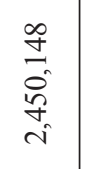 & 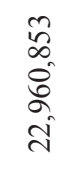 & $\begin{array}{c}m \\
\vec{n} \\
\tilde{n} \\
\dot{\delta} \\
\dot{n}\end{array}$ & 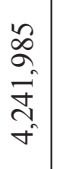 & 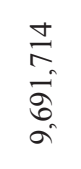 & $\begin{array}{l}\stackrel{n}{a} \\
\hat{n} \\
\stackrel{n}{0} \\
i\end{array}$ & 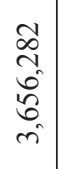 &  & 0 & 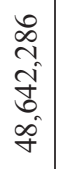 & $\begin{array}{l}\hat{\sigma} \\
\hat{\sigma} \\
0 \\
\hat{n} \\
\hat{\imath}\end{array}$ \\
\hline  & $\begin{array}{c}8 \\
0 \\
0 \\
0 \\
m \\
n \\
\infty \\
\infty\end{array}$ & & & & & & & & & & & & & & & & & &  \\
\hline $\begin{array}{l}n \\
\vdots \\
0 \\
0 \\
0\end{array}$ & 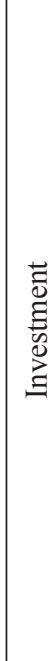 & 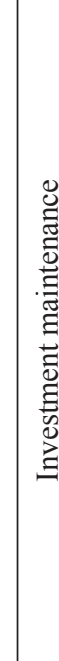 & 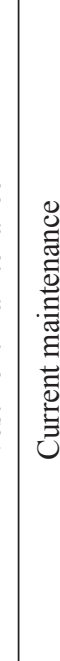 & 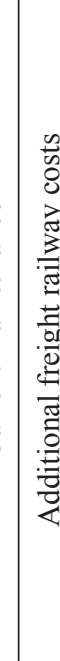 & 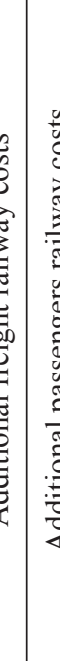 & 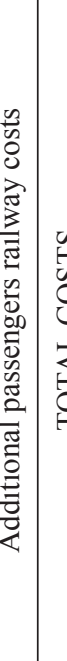 & $\begin{array}{l}0 \\
\vdots \\
0 \\
0 \\
\vdots \\
\vdots \\
\vdots \\
0\end{array}$ & 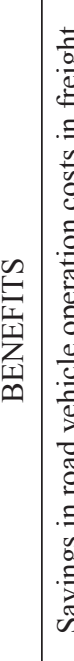 & 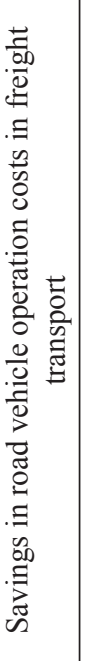 & 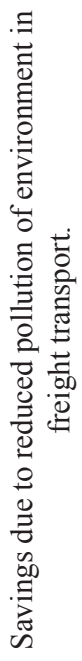 & 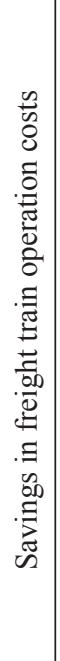 & 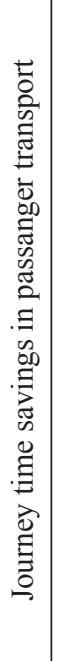 & 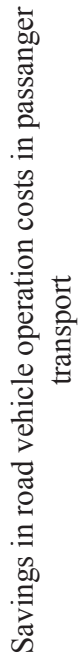 & 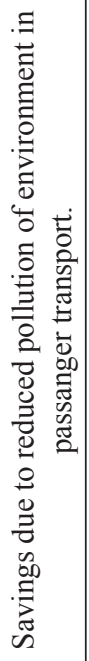 & 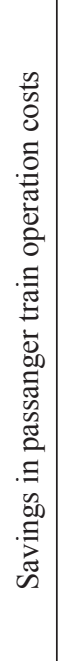 & 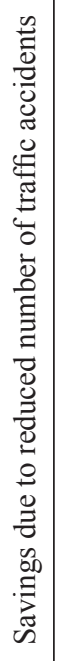 & 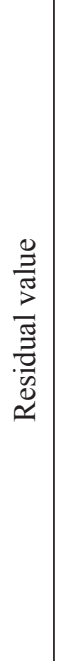 & 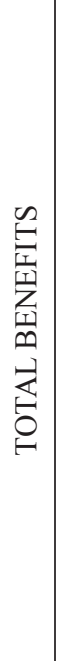 & 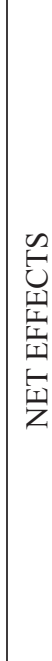 \\
\hline
\end{tabular}




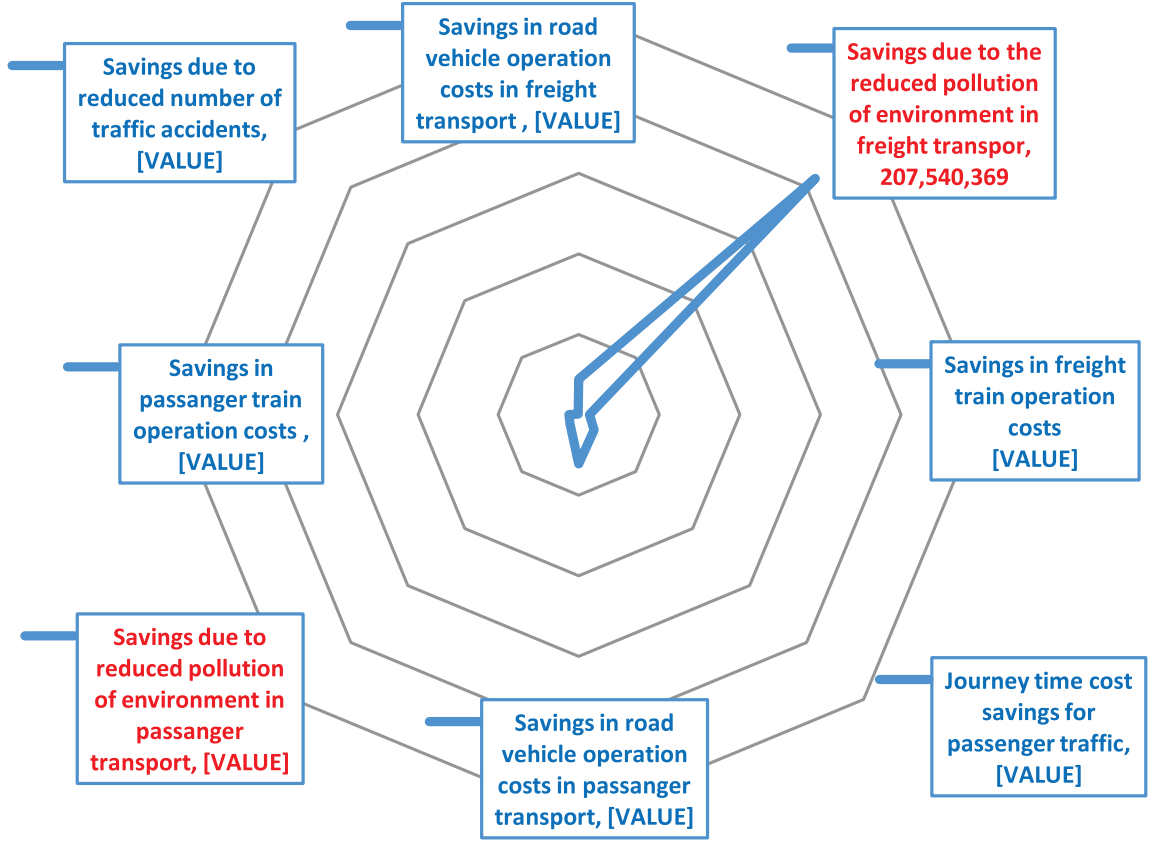

Fig. 1. Structure of socio-economic benefits from project realization in 2052 (EUR).

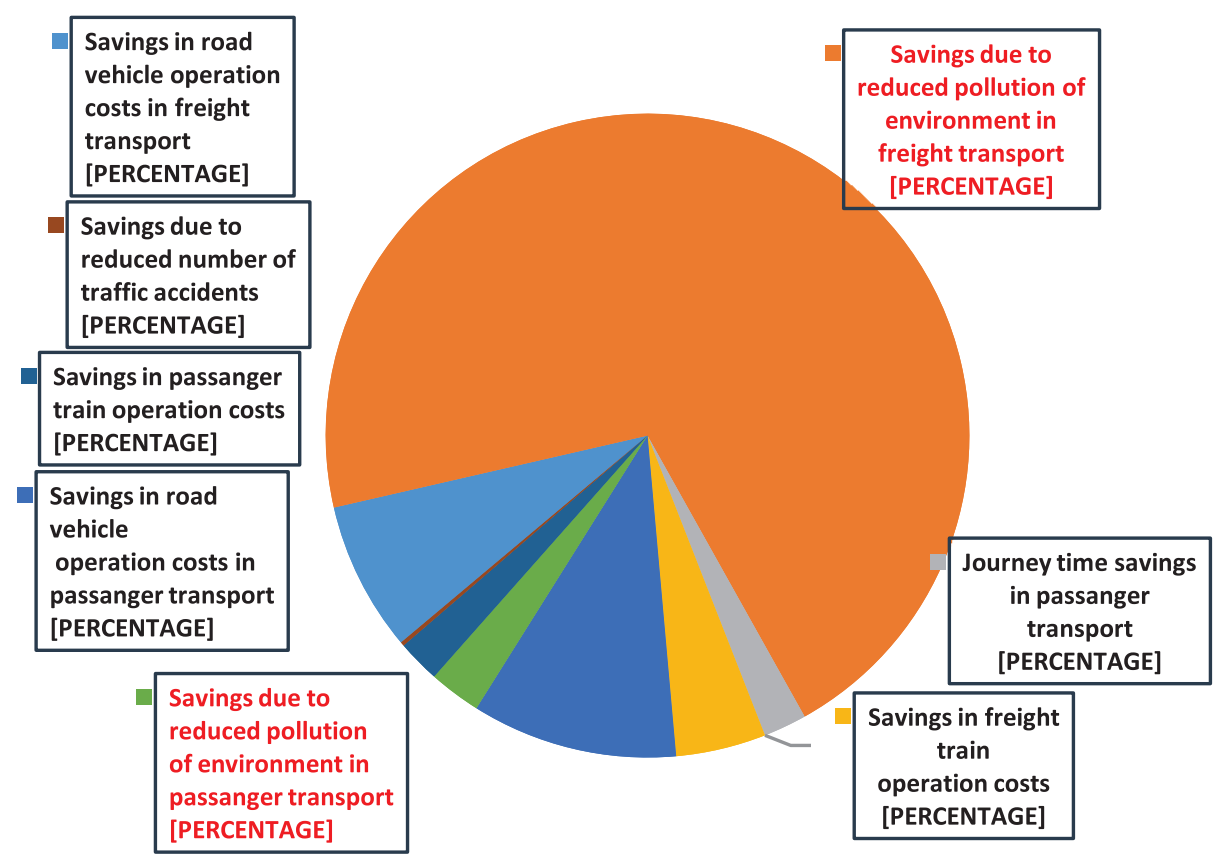

Fig. 2. Structure of socio-economic benefits from project realization in 2052 (in \%).

freight traffic from $70.5 \%$, while passenger traffic is $2.6 \%$ (Fig. 2).

\section{Conclusions}

The obtained results of the analyses of the financial and socio-economic feasibility of the reconstruction and modernization project of the railway in Serbia clearly confirmed the previously defined hypotheses in this paper. Namely, the financial effects of the investors (railway infrastructure owners) from the reconstruction and modernization of railway line projects in the countries of southeastern Europe are usually not satisfactory, as indicated by the financial appraisal of the project. The FIRR and FNPV indicators are negative, and the $\mathrm{FB} / \mathrm{C}$ indicator demonstrates an unfavorable ratio of benefits and costs. This confirms the first hypothesis in the paper. At the same time, the conclusion is that with large infrastructure projects in the public sector, the financial appraisal of the project is not sufficient for the decision to implement the project. 
Socio-economic analysis of this project has highlighted the high level of multiple socio-economic benefits from the reconstruction and modernization of the railway project, as a result of capacity expansion and increased transport re-routing (dominantly freight) from road to railway. EIRR is higher than the defined discount rate, the ENPV is positive, and the EB/C indicator shows a favorable ratio between the benefits and the project costs. This confirms a high level of socio-economic contribution of the project to society, which confirmed the second hypothesis in the paper.

Savings due to environment pollution reduction represent the dominant category in the overall socioeconomic benefits. For the total projection period 20232052 total savings due to environmental pollution reduction amount at close to EUR 2.29 billion, which is close to $60 \%$ of the total socio-economic benefits of the project. At the same time, the contribution of freight transport to savings due to environment pollution reduction for the total projection period is about $93 \%$, and the passenger is about $7 \%$. This indicates the expressed ecological dimension of the project and the confirmation of the third hypothesis.

In line with the above-mentioned observations, it can be concluded that the form of modern development is one that meets the present needs of people and does not jeopardize the ability of future generations to meet their own requirements. It is aimed at improving the individual's living standard, but with short-term, midterm and long-term environmental protection. The fact is that every type of transport carries a certain risk of environmental pollution, but these risks are different. Through its institutions, the international community insists on giving priority to rail transport and inland waterway transport. The air pollution and noise produced by the dominance of road transport has shown a series of weaknesses. Rail transport, as energyefficient, safe and environmentally friendly, is promoted by the common EU policy as a transport that can be modernized and thus be competitive to road transport. The data indicate that road transport, which dominantly participates in land transport and still largely depends on oil, has become a serious problem in many parts of the world. This problem can be overcome by eliminating road transport domination and developing transport in a spirit of sustainable development.

\section{Acknowledgements}

This paper contains the results of the research on the Railway Modernization Project, Novi Sad - Subotica State Border (Kelebija) section, financed and supported by the Government of the Republic of Serbia.

\section{Conflict of Interest}

The authors declare no conflict of interest.

\section{References}

1. UNECE, Transport for sustainable development in the ECE region, UNECE Transport Division, 2011.

2. VUJADINOVIC R., DAMJANOVIC M., SIMOVIC S. Environmental aspects of the passenger car fleet renewal in Montenegro, $23^{\text {rd }}$ International Transport and Air Pollution Conference TAP2019, 2019.

3. NAMINSE E., Y., ZHUANG., J. Economic Growth, Energy Intensity and Carbon Dioxide Emissions in China, Polish Journal of Environmental Studies, 27 (5), 2193, 2018.

4. CHESTER M.V., HORVATH A. Environmental assessment of passenger transportation should include infrastructure and supply chains", Environmental Research Letters, 4 (2), 2009.

5. DJUROVIC G., CETKOVIC, J., DJUROVIC V., JABLAN, N. The Paris Agreement and Montenegro's INDC: Assessing the Environmental, Social, and Economic Impacts of Selected Investments, Polish Journal of Environmental Studies, 27 (3), 1019, 2018.

6. SALEM M.Z., ALMUZAINI R.S., KISHAWI Y.S. The Impact of Road Transport on $\mathrm{CO}_{2}$ Atmospheric Concentrations in Gaza City (Palestine), and Urban Vegetation as a Mitigation Measure, Polish Journal of Environmental Studies, 26 (5), 2175, 2017.

7. MINTZIA D., KEHAGIA F., TSAKALIDIS A., ZERVAS E. A Methodological Framework for the Comparative Analysis of the Environmental Performance of Roadway and Railway Transport, Promet - Traffic \& Transportation, 30 (6), 721, 2018.

8. VUJADINOVIĆ R., PETROVIĆ S. Use of models for the calculation of $\mathrm{CO}_{2}$ emissions for passenger cars in Montenegro, $17^{\text {th }}$ Symposium on Thermal Science and Engineering of Serbia "Energy - Ecology - Efficiency" SIMTERM 2015, 1100, 2015.

9. DONG J.F., HUANG J.Y., WU R.W., DENG C. Delinking Indicators on Transport Output and Carbon Emissions in Xinjiang, China, Polish Journal of Environmental Studies, 26 (3), 1045, 2017.

10. FURFARI S. Energy efficiency of engines and appliances for transport on land, water, and in air, Ambio, 45 (1), 63, 2015.

11. WATSON I., ALI A., BAYYATI A. Sustainability of HSR as a mass transportation mode in terms of efficient use of natural resources, 360 High Speed Magazine, 6, 387, 2018.

12. WATSON I., ALI A., BAYYATI A. An investigation into the benefits and constraints of shifting freight traffic from roads onto high-speed railways, WIT Transactions on The Built Environment, Computers in Railways, 181 (16), 541, 2019.

13. WATSON I., ALI A., BAYYATI A. Investigation of the operational reliability of highspeed railway and possible measures of improvement, Railway Engineering, 2017.

14. FACT SHEETS ON THE EUROPEAN UNION, 2018 , Available online: www.europarl.europa.eu/factsheets/en (accessed on 1 February 2019).

15. FRIES N., HELLWEG S. LCA of land-based freight transportation: facilitating practical application and including accidents in LCIA, The International Journal of Life Cycle Assessment, 19, 546, 2014.

16. EUROPEAN COMMISSION, Electrification of the Transport System/Studies and reports/Directorate-General for Research and Innovation Smart, Green and Integrated Transport, Brussels, 2017. 
17. MERCHAN A.L., BELBOOM S., LEONARD A. Environmental impact assessment of rail freight intermodality, BIVEC/GIBET Transport Research Day, 2015.

18. TUCHSCHMID M., KNORR W., SCHACHT A., MOTTSCHALL M., SCHMIED M. Carbon Footprint and environmental impact of Railway Infrastructure", Öko-Institut e.V., commissioned by International Union of Railways (UIC), 2011.

19. NEMRY F., DEMIREL H. Impact of Climate Change on Transport: a focus on road and rail transport infrastructure, EUR 25553 - Joint Research Centre - Institute for Prospective Technological Studies, 2012.

20. VUJADINOVIC R. Air Quality Management And Sustainable Transport, $6^{\text {th }}$ International Conference ICQME 2011, 387, 2011.

21. LAKIC S. Sustainable development: crisis or regulation?, Scientific Monograph, 2017.

22. AKERMAN J., BANISTER D., DREBORG K., NIJKAMP P., SCHLEICHER-TAPPESER R., STEAD D., STEEN P. European transport policy and sustainable mobility, London: Routledge, 2000.

23. EUROPEAN INVESTMENT BANK, The Economic Appraisal of Investment Projects at the EIB, Projects Directorate, March, 2013.

24. DOBES L., LEUNG J. Wider Economic Impacts in Transport Infrastructure Cost-Benefit Analysis, Ag. 22 (1), 75, 2015.

25. JONES H., MOURA F., DOMINGOS T. Transportation Infrastructure Project Evaluation: Transforming CBA to Include a Life Cycle Perspective, Handbook of Sustainability Science and Research, 745, 2018.

26. JONES H., DOMINGOS T., MOURA F., SUSMAN J. Transport infrastructure project evaluation using costbenefit analysis: Improvements to valuing the asset through residual value - a case study, $93^{\text {rd }}$ Annual Meeting of the Transportation Research Board, 2014.

27. JONES H., MOURA F., DOMINGOS T. Transport infrastructure project evaluation using Cost-Benefit Analysis, Procedia - Social and Behavioral Sciences. 111, 400, 2014.

28. OECD, Cost-Benefit Analysis and the Environment: Further Developments and Policy Use, OECD Publishing, 2018, Available on: https://doi.org/10.1787/9789264085169en (accessed on 17 February 2019).

29. GUIDE TO COST-BENEFIT ANALYSIS OF INVESTMENT PROJECTS, Economic appraisal tool for Cohesion Policy 2014-2020, 2014.
30. VINING A.R., BOARDMAN A.E. Policy analysis in Canada: The state of the art. Toronto: University of Toronto Press, 2005.

31. GUHNEMANN A. SEA and sustainable development in the Baltic Sea region, OECD/ECMT Conference on Strategic Environmental Assessment for Transport, 1999.

32. BEDER S. Costing the earth: Equity, sustainable development and environmental economics. New South Wales: University of Wollongong, 2000.

33. INSTITUTE OF TRANSPORTATION, Studija izvodljivosti modernizacije željezničke pruge: Dionica Novi Sad - Subotica - državna granica (Kelebija) / Feasibility study on railway modernization: Novi Sad Subotica - state border (Kelebija) section, Belgrade, 2018 [In Serbian].

34. INFRASTRUCTURE RAILWAYS OF SERBIA, Izjava o mreži / Network Statement, 2017 [In Serbian].

35. MAIBACH M., SCHREYER C., SUTTER D., VAN ESSEN H.P., BOON B.H., SMOKERS R., SCHROTEN A., DOLL C., PAWLOWSKA B., BAK M. Handbook on estimation of external costs in the transport sector. Produced within the study Internalisation Measures and Policies for All external Cost of Transport (IMPACT), prepared for the European Commission, Version 1.1, Delft, CE, 2008.

36. EUROPEAN COMMISSION, Update of the Handbook on External Costs of Transport, 2014, Available on: https:/ec.europa.eu/transport/sites/transport/files/themes/ sustainable/studies/doc/2014-handbook-external-coststransport.pdf (accessed on 11 March 2019).

37. GENERAL TRANSPORT MASTER PLAN IN SERBIA, Završni izveštaj / Final Report, Italferr S.p.A., IIPP, NEA and Witteveen+Bos, 2009 [In Serbian].

38. INSTITUTE OF TRANSPORTATION, Rehabilitacija željezničke pruge u Srbiji: Tehnička pomoć za željezničku infrastrukturu - CBA za dionicu B - Stara Pazova - Novi Sad - Subotica - granica sa Mađarskom / Rehabilitation of the railway in Serbia: Technical assistance for railway infrastructure - CBA for section B - Stara Pazova - Novi Sad - Subotica - the border with Hungary, Italferr S.p.A., 2014 [In Serbian].

39. FEASIBILITY STUDY AND EIA, Modernisation of the Railway Line Stara Pazova - Novi Sad, Trademco and COWI, 2011. 
